\title{
Corrosion in the Oil and Gas Industry: An Increasing Challenge for Materials
}

\author{
TERESA E. PEREZ ${ }^{1,2}$ \\ 1.-Tenaris, Buenos Aires, Argentina. 2.-e-mail: tperez@tenaris.com
}

\begin{abstract}
Important reserves of oil and gas, which are left to be discovered and produced, are mainly concentrated in challenging locations and under severe conditions [i.e., high pressure (HP)/high temperature (HT)]. The HP/HT plus the presence of aggressive environments mean a highly demanding scenario for tubes used in producing oil and gas [oil country tubular goods (OCTG)]. Material property requirements include high mechanical properties at ambient and high temperatures (e.g., as high up to $200-250^{\circ} \mathrm{C}$ ). Additionally, if $\mathrm{H}_{2} \mathrm{~S}$ is present, resistance to sulfide stress cracking may be required, depending also on other environmental conditions. Even without $\mathrm{H}_{2} \mathrm{~S}$, contents of $\mathrm{CO}_{2}$, chlorides, and high temperatures and pressures can represent a risk of high corrosion rates. The improvement of some of the required properties of the materials (e.g., steels) can mean the impairment of other properties. Consequently, a careful balance is required and limits exist for the individual modification of the properties. The present article focuses on the two main environmental deterioration problems in the oil and gas business: (I) sulfide stress cracking and (II) $\mathrm{CO}_{2}$ corrosion. A description of the acting mechanisms and the effect of environmental and material factors are presented. Selection criteria and current material limitations are also discussed.
\end{abstract}

\section{INTRODUCTION}

Significant recoverable reserves of oil and gas left to be discovered and produced are mainly concentrated in challenge locations, such as deep-water offshore, remote arctic locations, and difficult-tomanage reservoirs with unconsolidated sands. Additionally, aggressive environments (i.e., high $\mathrm{H}_{2} \mathrm{~S}$ and/or $\mathrm{CO}_{2}$ contents) with high pressures and high temperatures are conditions to be faced by materials in many wells.

Materials and corrosion control technologies to be used under such demanding conditions and locations must be highly reliable due to the excessive cost of replacement or failure in these difficult-toaccess locations.

The main concerns for downhole tubulars from the related corrosion problematic point of view are environmental cracking and uniform or localized corrosion.

The total annual cost of corrosion in the oil and gas production industry is estimated to be US $\$ 1,372$ billion, broken down into $\$ 589$ million in surface pipeline and facility costs, $\$ 463$ million annually in downhole tubing expenses, and another $\$ 320$ million in capital expenditures related to corrosion. ${ }^{1}$ It is widely recognized within the oil and gas industry that effective management of corrosion will contribute toward not only cost reduction but also compliance with safety, health, and environmental policies.

Even though slightly different definitions for high-pressure, high-temperature (HP/HT) conditions are used, most companies currently categorize their operations, products, or tools into the three main tiers ${ }^{2}$ (Fig. 1).

The increment of temperatures and pressures in the wells means that materials with higher mechanical properties, even at the upper range of operation temperatures, are required. Moreover, the aggressiveness of the environment has to be considered.

$\mathrm{CO}_{2}$ and $\mathrm{H}_{2} \mathrm{~S}$ gases in combination with liquid water are the main causes of corrosion in oil and gas production. In addition, it is normal practice to reinject production water downhole to maintain the 


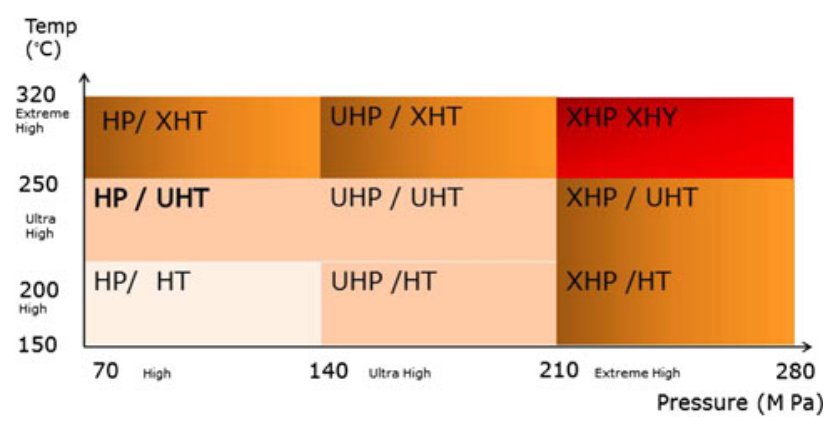

Fig. 1. Matrix of high-pressure/high-temperature operation.

reservoir pressure and stability as well as perform water flooding (using seawater or fresh water sources) to drive oil out of the formation. As a field ages, the ratio of water to oil in the produced fluids increases and can reach levels of $95 \%$ or higher. This rise in water content implies an increase in corrosion problems. Internal corrosion caused by produced fluids is the most costly of the corrosion problems in the oil and gas industry since internal mitigation methods cannot be easily maintained and inspected. Therefore, as a field ages, corrosion control becomes more expensive. Approximately $60 \%$ of oilfield failures are related to $\mathrm{CO}_{2}$ corrosion; it can produce not only general corrosion but also localized corrosion, which is a much more serious problem.

Regarding $\mathrm{H}_{2} \mathrm{~S}$, three are the environmental degradation-related phenomena in production and transportation: weight loss corrosion in sour service conditions, localized corrosion (mainly pitting), and sulfide stress cracking (SSC).The SSC risk has been given the highest level of attention because of its dramatic safety impact. Materials, such as carbon steels, can suffer catastrophic failures due to the presence of $\mathrm{H}_{2} \mathrm{~S}$ under certain levels of pressure, temperature, $\mathrm{pH}$, and tensile stresses. In fact, crack propagation can take place very fast and produce very serious economic and environmental problems. Due to this fast cracking development, even short and unexpected exposure must be considered during material selection. As MR0175/ISO $15156^{3}$ states, the definition of exposure conditions shall include both intended exposures and unintended exposures that may result from the failure of primary containment or protection methods. This is an important difference in material selection when a corrosion problem is the issue. In this case, it takes longer for damage to occur. Therefore, exposure time can be a criterion to define "acceptable corrosion damage."

In summary, the material selection must focus first on SSC as the most relevant aspect and the aim must be to avoid any risk of cracking. After that the corrosion risk has to be considered.

Carbon and low-alloy carbon steels (LAS) are the first alternative to be considered in material selection not only from the cost point of view but also due to their availability. Therefore, big efforts have been made to increase the corrosion resistance of carbon and low-alloy steels. When the environment is too aggressive for bare carbon steels, one option to reduce corrosion problems is the use of inhibitors. However, under highly aggressive environmental conditions and high temperatures, more expensive materials, such as corrosion-resistant alloys (CRAs), may be required.

Another challenging scenario for oil country tubular goods (OCTG) products is related to carbon capture and storage technologies. These technologies are some of the mitigation options to reduce the impact of $\mathrm{CO}_{2}$ on the global climate. $\mathrm{CO}_{2}$ can be stored in geological formations, e.g., deep saline formations and depleted oil and gas reservoirs. Existing or new wells can be used for injecting $\mathrm{CO}_{2}$ into underground storage facilities.

In general, the downhole injection system consists of a casing pipe, a downhole tubing, and a wellhead to prevent blowout. As the underground pressure must be overcome, the system operates at a high pressure to inject the $\mathrm{CO}_{2}$ into the storage facility. ${ }^{4}$ $\mathrm{CO}_{2}$ is usually injected in a supercritical state.

Depending on the $\mathrm{CO}_{2}$ source, injected gas composition and water content vary and different contaminants like $\mathrm{SO}_{x}, \mathrm{NO}_{x}, \mathrm{H}_{2} \mathrm{~S}$, and/or $\mathrm{O}_{2}$ can be present. These impurities when present in even moderate amounts have an important effect; they dissolve readily in water and induce the formation of an aqueous phase at a much lower water concentration than the solubility limits reported for pure $\mathrm{CO}_{2}$ and $\mathrm{CO}_{2}$ contaminated with hydrocarbons. If liquid water is present with those contaminants in solution, serious corrosion problems can take place. $^{5,6}$

In summary, $\mathrm{CO}_{2}$ injection wells for sequestration are highly challenging in many ways mainly due to the fluids and pressures they must handle and the long-term duration for which full well integrity is required. ${ }^{7}$ The corrosion risk related to the feasibility of having liquid water plus aggressive species in solution has to be considered.

The present article focuses mainly on the environmental deterioration problems in the oil and gas business previously mentioned. A description of acting mechanisms and the effect of environmental and material factors are presented. Selection criteria and current material limitations are also discussed.

\section{SULFIDE STRESS CRACKING}

The first cases of SSC in the oil and gas industry were reported in the tubing and casing of gas wells in the United States and Canada in 1950-1951.

The presence of hydrogen sulfide $\left(\mathrm{H}_{2} \mathrm{~S}\right)$ is an ever increasing problem in the oilfield, whether the origin is biological or formation dependent. Biogenic formation by the microbial action of sulfate reducing bacteria (SRB) is one of the main reasons for $\mathrm{H}_{2} \mathrm{~S}$ progressive concentration increase because SRB 
reduce existing sulfate ions to $\mathrm{H}_{2} \mathrm{~S}$ gas. One of the most common techniques for enhanced oil recovery is injection water, and nonadequately treated injected water has been a source of bacteria contamination of aquifers.

\section{Hydrogen Embrittlement Mechanisms}

It is well known that the presence of atomic hydrogen in solid solution severely degrades the fracture resistance of high-strength metallic alloys (e.g., carbon and low-alloy steels). This process is known as hydrogen embrittlement or hydrogen-induced cracking. The hydrogen deleterious effect has a relevant industrial and economic impact being, at the same time, a challenge from the scientific point of view. Due to the previously mentioned facts, an intensive effort has been done to understand the involved mechanisms and hundreds of papers have been published. ${ }^{8-14}$ Despite those efforts, hydrogen embrittlement mechanisms continue to be widely discussed and different theories have been proposed. However, a generally recognized common feature of all the theories that attempt to explain embrittlement in nonhydride former materials is that some critical concentration of hydrogen must be reached at a potential crack site for failure to initiate. In this context, sites in which hydrogen is preferentially accumulated are key points to explaining crack initiation. These sites are called hydrogen traps, and by definition, they have higher binding energy than the lattice and, therefore, they are potential crack initiators. ${ }^{15,16}$ According to their binding energy, they can be categorized in irreversible/deep or flat/reversible traps. Binding energy for flat traps is higher than the one for the lattice, but at the same time, hydrogen interchange with the lattice can occur. Although there is no consensus about the role of each trap on embrittlement, traps have been extensively studied, particularly in iron alloys. Some authors ${ }^{17,18}$ propose that only mobile hydrogen in solution or in a flat trap is involved in fracture. Pressouyre and Bernstein, ${ }^{19-21}$ suggest that initiation will be produced at irreversible traps since they can accumulate a large amount of hydrogen and achieve the critical concentration. In their approach, mobile hydrogen only accelerates or retards crack initiation depending on the charging conditions.

Atomic hydrogen can be introduced globally throughout the microstructure by manufacturing operations (e.g., casting, welding, surface-chemical cleaning, electrochemical machining, electroplating, and heat treatment) as well as by environmental exposure (e.g., cathodic electrochemical reactions at low temperatures and gaseous hydrogen exposure at elevated temperatures).

A very simplified description of the mechanism of atomic hydrogen introduction in a material can be presented considering the following steps. Atomic hydrogen is produced by the proton reduction and its chemiadsorption on the surface $\left(\mathrm{H}_{\mathrm{ads}}\right)$ (Eq. 1). This $\mathrm{H}_{\text {ads }}$ can be consumed either by $\mathrm{H}$ combination (Eq. 2) or by absorption into the bulk of the material (Eq. 3). However, the actual mechanism includes a combination of chemical and electrochemical steps occurring simultaneously. ${ }^{22,23}$ Concurrently, the anodic corrosion reaction of the steel takes place on the surface:

$$
\begin{gathered}
\mathrm{H}^{+}+1 \mathrm{e}^{-} \Leftrightarrow \mathrm{H}_{\mathrm{ads}} \\
2 \mathrm{H}_{\mathrm{ads}} \Leftrightarrow \mathrm{H}_{2} \\
\mathrm{H}_{\mathrm{ads}} \Leftrightarrow \mathrm{H}_{\mathrm{abs}} \Leftrightarrow \text { Diffusion into the material }
\end{gathered}
$$

The presence of tensile stresses (applied and/or residuals) is recognized as another required factor for hydrogen embrittlement cracking. The effect of stresses on hydrogen solubility was first addressed by Beck et al. ${ }^{24}$ in pure iron and in AISI 4340 steel. Different relationships were proposed to express the effect of tensile stresses on solubility. ${ }^{25-28}$

As is schematically shown in Fig. 2, the crack propagates when a critical concentration of atomic hydrogen is reached at a certain point of the material. This threshold depends not only on the material characteristics and the temperature but also on the tensile stress level and the hydrogen concentration itself because they also affect the fracture toughness of the material.

The presence of electronegative species known to poison hydrogenation recombination reactions on transition metals drastically increases the adsorbed atomic hydrogen uptake. ${ }^{29}$ In oil and gas applications, $\mathrm{H}_{2} \mathrm{~S}$ has the deleterious effect of promoting hydrogen uptake. ${ }^{30,31}$ Although many explanations have been proposed to account for these effects, the detailed mechanism of the action of $\mathrm{H}_{2} \mathrm{~S}$ is not yet fully understood. ${ }^{32-35}$

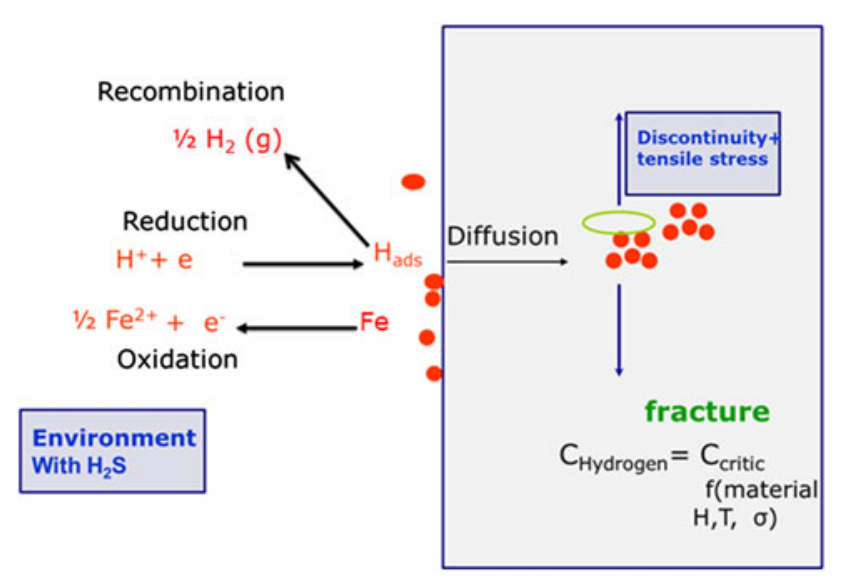

Fig. 2. Schematic representation of SSC mechanism. 


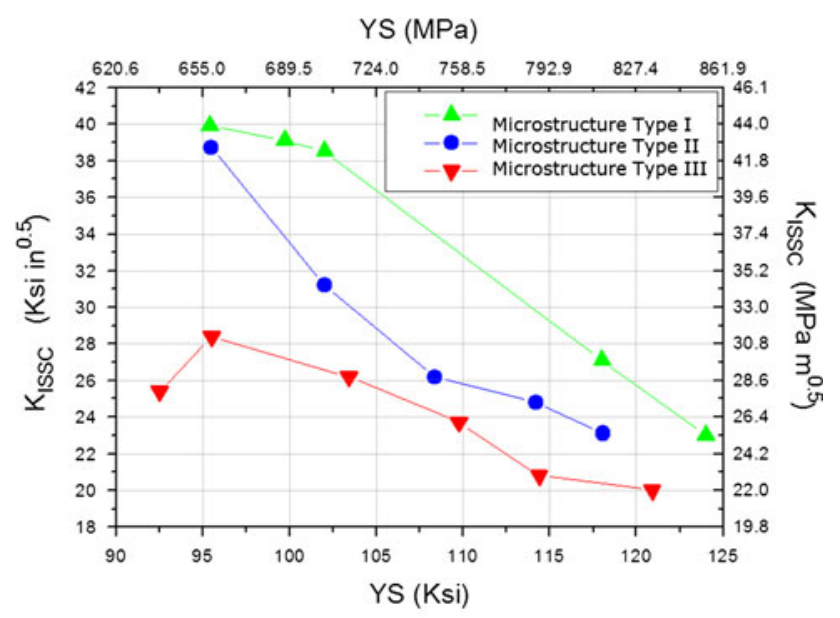

Type I: Tempered martensite + fine ferrite grains + very fine carbides Type II: Tempered martensite with less quantity of fine carbides Type III: Tempered martensite + upper bainite

Fig. 3. Effect of mechanical properties and microstructure on cracking resistance of LAS (expressed in terms of a critical stress intensity factor). Test solution A NACE TM0177-2005. ${ }^{36}$.

\section{Development of High-Strength LAS for Sour Service Environment}

As previously stated, carbon and low-alloy steels are the first alternative in material selection for oil and gas exploration, drilling, and production. This is particularly applicable for sections that are not continuously in contact with production fluids, but the exposure to the primary aggressive environment is usually accidental and of short duration (for instance, due to a tubing leak). Production casing above the packer is an example of this category. If a sour environment is present, the resistance to SSC has to be ensured. For deep wells, high mechanical properties will be the additional requirements.

As shown in Fig. $3,{ }^{36}$ the $\mathrm{H}_{2} \mathrm{~S}$ cracking resistance (expressed in terms of a critical stress intensity factor, KISSC ${ }^{37}$ ) drastically decreases as the mechanical resistance increases.

Consequently, the development of LAS with high mechanical properties and good resistance to $\mathrm{H}_{2} \mathrm{~S}$ cracking is an important and very challenging aim.

The role of the microstructure on SSC resistance was recognized many years ago. ${ }^{36,38}$ Quenched and tempered microstructures with low dislocation density and a homogenous and fine distribution of spherical carbides have shown the best performance. Meanwhile, the presence of upper bainite is highly detrimental. Additionally, many publications show a clear relationship between microstructural refinement and SSC resistance.

Steel design and production process conditions have to be defined to get the mentioned desirable microstructural characteristics.

$\mathrm{Nb}$ and Ti microalloying additions and controlled rolling conditions are used to avoid excessive grain growth during this process. A double-quenched and tempered process is sometimes used to get an extra grain size refinement. The austenization temperature prior to quenching must be selected as low as possible to get a fine grain in a consistent way with a full dissolution of iron carbides and complete homogenization of carbon.

The chemical composition plus quenching conditions have to ensure adequate hardenability to avoid nondesirable microstructures after quenching even for heavy walls.

Increasing the tempering temperature as much as possible by adjusting the chemical composition (Cr-Mo and microalloying $\mathrm{V}-\mathrm{Nb}$ ) is recommended to get the optimum final microstructure.

The cleanness of the steel is another key factor because inclusions can act as nucleation sites of cracks. Additionally the content of elements such as $\mathrm{P}$ and $\mathrm{S}$ has to be minimized.

Tensile residual stresses and cold deformation have to be avoided as well. Stress relief requirements are specified in ISO 15156 for materials that are cold deformed after heat treatment.

Applying all of this background together with tight process control conditions for LAS pipes of 110 grades (110 ksi as minimum yield strength) have been developed, and the Grade C110 is currently included in API 5CT. ${ }^{39}$ Additionally, proprietary grades with higher mechanical properties (minimum yield strength of $125 \mathrm{ksi}$ ) have been developed.

\section{Selection of Materials Suitable to Be Used in $\mathrm{H}_{2} \mathrm{~S}$-Containing Environments}

ISO 15156 gives requirements and recommendations for the selection and qualification of materials for sour environments. Regarding carbon and low alloy steels, ISO 15156-Part 2 presents two different options for the selection:

- Option 1: Only considers the $\mathrm{H}_{2} \mathrm{~S}$ partial pressure as the defining parameter. If the partial pressure of $\mathrm{H}_{2} \mathrm{~S}$ in the gas is $\geq 0.3 \mathrm{kPa}(0.05 \mathrm{psi})$, SSCresistant steels shall be selected. The application of API 5CT/ISO11960 grades depends on material requirements (i.e., chemical composition, method of manufacture, strength, hardness, heat-treatment condition, and microstructure) and on minimum exposure service temperatures. For proprietary steel grades, in addition to previous requirements, SSC resistance shall be demonstrated by testing each test batch.

- Option 2: Allows the user to qualify and select materials for SSC resistance for specific sourservice applications or for ranges of sour service. In situ $\mathrm{pH}$ and $\mathrm{H}_{2} \mathrm{~S}$ partial pressure are considered to define regions with different severity (Fig. 4).

The selection can be performed if requirements regarding mechanical properties (which depend on the application region) are filled. Additionally, low-alloy steels may be tested and qualified for use 


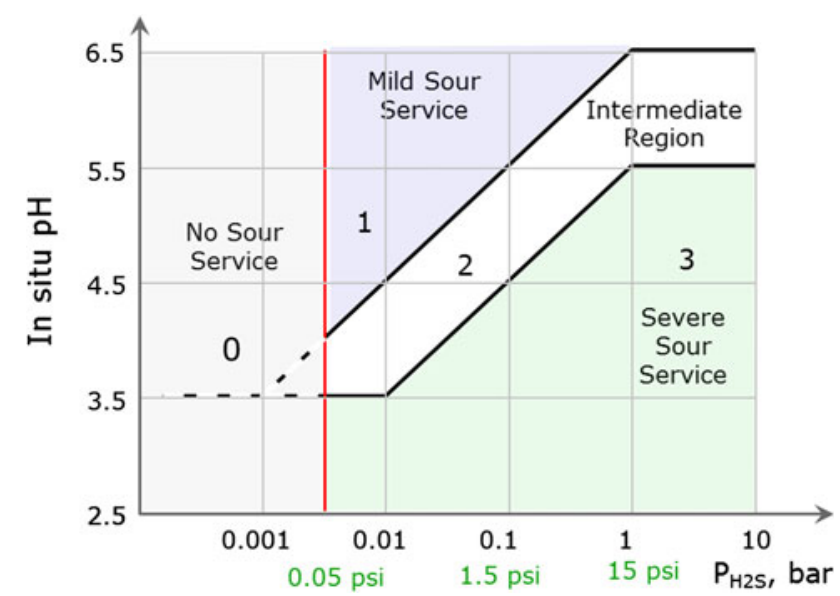

Fig. 4. Regions of environmental severity with respect to the SSC of carbon and low-alloy steels ${ }^{3}$.

under specific sour-service conditions or for use throughout a given SSC region.

The requirements and recommendations for the selection and qualification of CRAs and other alloys for service in equipment used in oil and natural gas production and natural gas treatment plants in $\mathrm{H}_{2} \mathrm{~S}$-containing environments are given in NACE MR0175/ISO 15156-Part 3. The acceptable metallurgical conditions and environmental limits for which CRAs are expected to resist cracking are also provided in Part 3.

\section{$\mathrm{CO}_{2}$ CORROSION}

$\mathrm{CO}_{2}$ or "sweet" corrosion is by far the most prevalent form of corrosion encountered in oil and gas production. ${ }^{40,41}$ Early cases of $\mathrm{CO}_{2}$ corrosion were reported in gas wells located in Texas in the 1940s. Dry $\mathrm{CO}_{2}$ is noncorrosive to steels and alloys in downhole conditions, but dissolved carbon dioxide in the produced or condensed water can result in very high corrosion rates particularly when a localized attack takes place. Even corrosion resistance alloys have limits in their resistance depending mainly on their chemical composition. The $\mathrm{CO}_{2}$ corrosion process is complex, and its understanding still requires further work. ${ }^{42}$

\section{$\mathrm{CO}_{2}$ Corrosion Mechanisms and Morphologies}

In oil and gas wells, produced fluids could contain significant proportions of $\mathrm{CO}_{2}$. Carbon dioxide will dissolve in the aqueous phase associated with hydrocarbon production, forming carbonic acid (Eq. 4):

$$
\mathrm{CO}_{2}(\mathrm{~g})+\mathrm{H}_{2} \mathrm{O}(\mathrm{l}) \Leftrightarrow \mathrm{H}_{2} \mathrm{CO}_{3}(\mathrm{aq})
$$

Three main cathodic (Eqs. 5a-c) reactions and one anodic (Eq. 6) reaction can be identified:

$$
2 \mathrm{H}_{2} \mathrm{CO}_{3}+2 \mathrm{e} \Leftrightarrow 2 \mathrm{H}_{2}+2 \mathrm{HCO}_{3}^{-}
$$

$$
\begin{gathered}
2 \mathrm{H}_{2} \mathrm{CO}_{3}+2 \mathrm{e} \Leftrightarrow 2 \mathrm{H}_{2}+2 \mathrm{CO}_{3}^{-} \\
2 \mathrm{H}^{+}+2 \mathrm{e} \Leftrightarrow \mathrm{H}_{2} \\
\mathrm{Fe} \Leftrightarrow \mathrm{Fe}^{2+}+2 \mathrm{e}
\end{gathered}
$$

During this corrosion process, iron carbonate $\mathrm{FeCO}_{3}$ can be formed on the steel surface (according to Eqs. 7-9), if the limit of solubility of $\mathrm{FeCO}_{3}$ is reached. The solubility depends on the solution $\mathrm{pH}$, $\mathrm{CO}_{2}$ partial pressure, and temperature. ${ }^{43-46}$ This precipitate can act as a protective layer that reduces the uniform corrosion rate of the steel. However, under certain environmental conditions, when the $\mathrm{FeCO}_{3}$ protective layer is partially destroyed, localized corrosion can take place:

$$
\begin{gathered}
\mathrm{Fe}^{2+}+\mathrm{CO}_{3}^{2-} \Leftrightarrow \mathrm{FeCO}_{3} \\
\mathrm{Fe}^{2+}+2 \mathrm{CO}_{3} \mathrm{H}^{-} \Leftrightarrow \mathrm{Fe}\left(\mathrm{CO}_{3} \mathrm{H}\right)_{2} \\
\mathrm{Fe}\left(\mathrm{CO}_{3} \mathrm{H}\right)_{2} \Leftrightarrow \mathrm{FeCO}_{3}+\mathrm{CO}_{2}+\mathrm{H}_{2} \mathrm{O}
\end{gathered}
$$

The morphology of the $\mathrm{CO}_{2}$ corrosion attack can be uniform. Additionally, three main forms of localized corrosion can be identified: pitting (Fig. 5a), mesa attack (Fig. 5b), and flow-induced localized corrosion (Fig. 5c).

Pitting of carbon and low-alloy steels typically takes place at low-flow velocities and around the dew-point temperatures in gas wells. Pitting in oil wells with scaling tendency has also been observed. The pitting tendency increases with temperature and $\mathrm{CO}_{2}$ partial pressure. The actual mechanisms of pitting of carbon steels in $\mathrm{CO}_{2}$ environments are not clear, and there are no rules for its prediction.

Mesa attack is associated with low-to-medium flow, where a protective carbonate film is formed but it is unstable. Bare areas act as an anode of a galvanic cell where surrounding film-covered areas operate as the cathode.

Flow-induced corrosion is related to high-flow velocities and turbulence. Pits, mesa attack zones, or particular geometries can produce local turbulence. Turbulence, in turn, may destroy existing protective scales and prevent reformation on the exposed metal.

\section{Factors that Determine the Severity of $\mathrm{CO}_{2}$ Corrosion of Carbon and Low-Alloy Steels}

The actual morphology of the corrosion, as well as the corrosion rate, will depend mainly on the formation of a protective layer of corrosion products, its effective adherence, and its capability of reforming in case of local damage. Consequently, the severity 

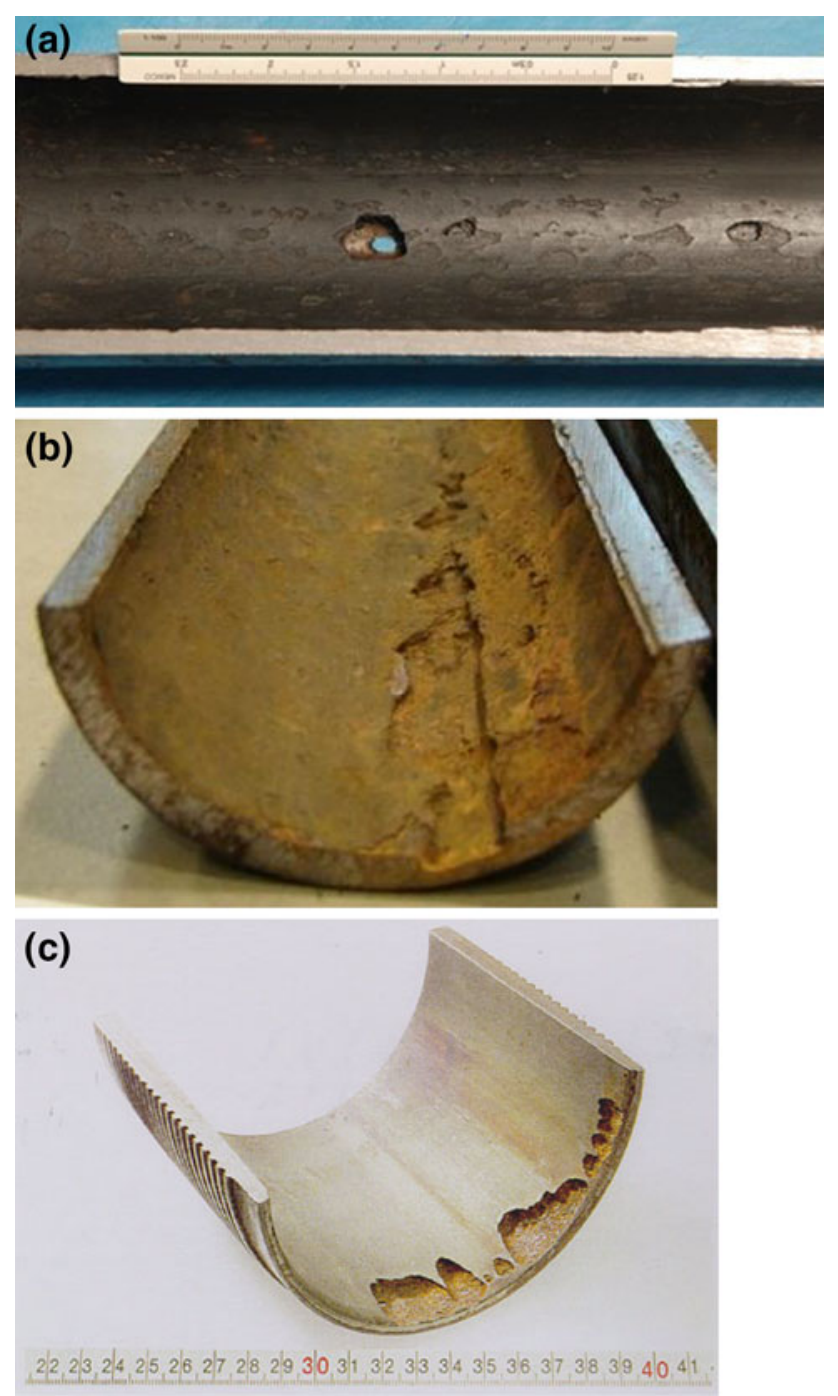

Fig. 5. (a) Pitting attack. (b) Mesa attack. (c) Flow-induced localized attack.

of carbon dioxide corrosion of carbon and low-alloy steels will be influenced by all those factors that can affect the corrosion layer formation and properties. The following environmental parameters will have a interactive effect:

- $\mathrm{CO}_{2}$ partial pressure

- Temperature

- Water content (water cut) and water chemistry

$-\mathrm{pH}$

- Flow velocity and type

- Presence of $\mathrm{H}_{2} \mathrm{~S}$, oxygen, and organic acids

The corrosion severity increases for high $\mathrm{CO}_{2}$ partial pressure, flow velocity, water content, and low $\mathrm{pH}$. The effect of $\mathrm{CO}_{2}$ partial pressure and temperature on the corrosion rate of low-alloyed carbon steel is presented in Fig. 6. Temperature affects the nature and characteristics of the corrosion product, which influence corrosion. The

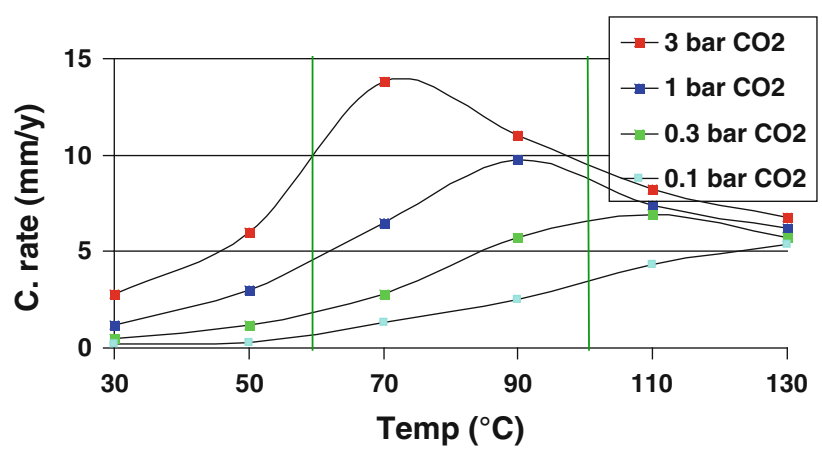

Fig. 6. Effect of temperature and $\mathrm{CO}_{2}$ partial pressure on the corrosion rate of a LAS.

uniform corrosion rate tends to present a maximum at a certain temperature (around $60-100^{\circ} \mathrm{C}$ ) depending on the other environmental conditions (e.g., $\mathrm{CO}_{2}$ partial pressure and $\mathrm{pH}$ ).

Organic acids are short-chain carboxylic acids, mainly acetic acid (C2) but also some propionic and butyric acids (C3 and C4). They are usually produced with the hydrocarbon in both gas and oil production wells. They strongly influence $\mathrm{CO}_{2}$ corrosion process and hence affect corrosivity assessment and predictions.

When organic acids are present, the corrosion problems can appear at considerably lower $\mathrm{CO}_{2}$ partial pressures. ${ }^{47-52}$ Their effect and the acting mechanisms are still under discussion.

In condensed water, the free acetic acid content (HAc) is physically dissolved from the gas (or oil) phase, and this induces an over acidification of the $\mathrm{CO}_{2}$ solution. When HAc becomes the dominant acid, it increases the solubility of the corrosion products, which means increasing the iron content $\left(\mathrm{Fe}_{\text {sat }}\right)$ at the saturation of the corrosion products $\left(\mathrm{FeCO}_{3}\right)$. Relative quantities of $\mathrm{HAc}$ and $\mathrm{CO}_{2}$ will determine which one is the acting acid. For gas fields, empirical thresholds have been proposed (Table I).

The values reported in Table I are only estimations. The real mechanisms are not completely understood and the different parameters have strong interactions between them.

Crolet et al. ${ }^{53}$ tried to identify what might differentiate fields with and without organic acids with respect to the currently understood mechanisms of $\mathrm{CO}_{2}$, and to explain the reported threshold values. They showed that empirical field thresholds of $1 \mathrm{mM}$ and $0.1 \mathrm{mM}$ HAc actually correspond to the same acidifying power as 2 bar and 0.2 bar of pure $\mathrm{CO}_{2}$, e.g., nearly the API limits of the 1958 limit values for $\mathrm{CO}_{2}(<0.2$ bar low corrosiveness; $>2$ bar high corrosiveness).

In reservoir water, the free HAc is chemically produced from the total acetate content $\left(\mathrm{Ac}_{\mathrm{tot}}\right)$ and the dissolved $\mathrm{CO}_{2}$, and this does not practically change anything on the $\mathrm{Fe}_{\text {sat }}$. It just occurs that in strongly buffered waters, the HAc value in $\mathrm{mM}$ is always close to that of $\mathrm{Fe}_{\text {sat }}$ in ppm, so that the free 
Table I. Proposed empirical thresholds for acetic acid in gas wells

\begin{tabular}{lcc}
\hline Free HAc (meq/L) & Dominating acid & Corrosion process governed by \\
$<0.1$ & $\mathrm{CO}_{2}$ becomes the dominant acid & $\mathrm{CO}_{2}$ corrosion \\
$0.1-1$ & Mixed dominance of both acids & Mixed corrosion \\
$>1$ & Essentially HAc & $\mathrm{HAc}^{2}$ corrosion. Independent of $\mathrm{CO}_{2}$ \\
\hline
\end{tabular}

HAc is not too bad a marker of the solubility of the corrosion products. Thresholds of HAc are then low because the corrosion layers can be sufficiently protective only at low $\mathrm{Fe}_{\text {sat. }}{ }^{53}$

The effect of the microstructure of LAS on $\mathrm{CO}_{2}$ corrosion has been widely studied, but many issues are still uncertain and contradictory results can be found in the literature. ${ }^{54-59}$

Regarding the effect of steel composition, the positive influence of low $\mathrm{Cr}$ additions $(\sim 3 \%)$ on $\mathrm{CO}_{2}$ corrosion performance of standard carbon steel is reported in the literature. ${ }^{60,61}$ Energy-dispersive $\mathrm{x}$-ray and Fourier transform infrared analysis showed that chromium-enriched surface films (iron/ chromium oxy-hydroxides) are formed during the corrosion process causing a corrosion rate reduction. A new generation of low-carbon $3 \% \mathrm{Cr}$ microalloyed steels has been developed as an intermediate option for well completions in terms of corrosion resistance and economy. ${ }^{62,63}$ The material showed good performance in mature oil wells, with high water cut (even $>90 \%$ ), high chloride content (in cases higher than $150,000 \mathrm{mg} / \mathrm{L}$ ), and moderate $\mathrm{CO}_{2}$ partial pressure moderate (up to 1 bar or slightly higher). ${ }^{64,65}$

\section{Effect of $\mathrm{H}_{2} \mathrm{~S}$ on $\mathrm{CO}_{2}$ Corrosion: Limits Between Sweet and Sour Corrosion}

The presence of small concentrations of $\mathrm{H}_{2} \mathrm{~S}$ can have a significant effect on $\mathrm{CO}_{2}$ corrosion; this is because iron sulfide can precipitate as the corrosion product in $\mathrm{CO}_{2} / \mathrm{H}_{2} \mathrm{~S}$ environments. Depending on the exposure conditions, different forms of $\mathrm{FeS}$ can form (Fig. 7), ${ }^{66}$ and their specific corrosion protectiveness may be different. A significant amount of information is reported in the literature regarding the formation of the various $\mathrm{FeS}$ species as well as the impact that each has on further corrosion. However, there is still a great deal that is not known. For example, there are currently no generally accepted prediction algorithms for any form of $\mathrm{H}_{2} \mathrm{~S}$ corrosion. There are also still a number of unknowns about the corrosion reactions that lead to pitting, which is the most common mode of sour service equipment failure. ${ }^{67}$

To determine how much $\mathrm{H}_{2} \mathrm{~S}$ is required to turn a system from sweet to sour corrosion, different rules of thumb have been used. In the 1980s, Dunlop et al. ${ }^{68}$ proposed the use of a $\mathrm{CO}_{2} / \mathrm{H}_{2} \mathrm{~S}$ ratio of 500 at $25^{\circ} \mathrm{C}$ to determine whether the corrosion product will be $\mathrm{FeCO}_{3}$ or $\mathrm{FeS}$. For values $>500$, the product will be $\mathrm{FeCO}_{3}$ and $<500$ the product will be $\mathrm{FeS}$. Other authors proposed a ratio of $\mathrm{CO}_{2} / \mathrm{H}_{2} \mathrm{~S}$ lower

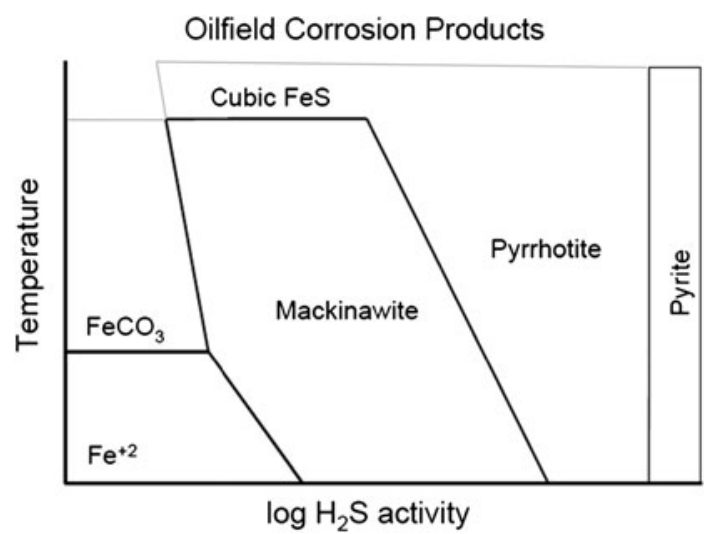

Fig. 7. Corrosion product formation as a function of temperature and $\mathrm{H}_{2} \mathrm{~S}^{66}$.

than 20 to have sour corrosion, while a mixed regime is considered when the ratio ranges between 20 and 500 and sweet corrosion for values higher than 500 .

The ratio of 500 for the $\mathrm{CO}_{2} / \mathrm{H}_{2} \mathrm{~S}$ is referenced in a number of industry documents. ${ }^{69,70}$ However, some authors ${ }^{71}$ consider that the use of the $\mathrm{CO}_{2} / \mathrm{H}_{2} \mathrm{~S}$ ratio as a rule of thumb to determine sweet versus sour corrosion conditions is not recommended because the effective ratio is too sensitive to thermodynamic input data quality to be a useful engineering tool. Existing computer tools that model corrosion chemistry and can calculate $\mathrm{FeCO}_{3}$ and $\mathrm{FeS}$ formation should be used instead.

A review of a wide number of field cases ${ }^{72,73}$ reports quantitative information about sour weight loss corrosion and proposes possible mechanisms. The fluid corrosiveness is classified into three categories, from a negligible corrosiveness in 40\%-50\% of the cases (both in oil and gas production), to a moderate one (typically within $1 \mathrm{~mm} /$ year) in most of other cases, and lastly to a very severe corrosion (10 $\mathrm{mm} /$ year, even in apparently mild conditions) in a few cases. The flow velocity and flow regime are shown to be the most leading factors of the transition between negligible and intermediate and severe corrosion categories. Very severe corrosion cases require "pit promoters" (sulfur, oxygen, and bacteria) and a "galvanic effect" with surrounding noncorroding surfaces. On the other hand, the $\mathrm{H}_{2} \mathrm{~S}$ and $\mathrm{CO}_{2}$ partial pressure as well as the $\mathrm{pH}$ or the $\mathrm{H}_{2} \mathrm{~S} /$ $\mathrm{CO}_{2}$ ratio does not influence the corrosion likelihood if the $\mathrm{CO}_{2} / \mathrm{H}_{2} \mathrm{~S}$ ratio is lower than 20 . 
Other references ${ }^{74}$ also report that sour oil wells are never corrosive at least above $3 \% \mathrm{H}_{2} \mathrm{~S}$ in the acid-gas mixture. The same is true for gas wells with an active aquifer, i.e., producing their reservoir water in the same way as oil wells. Conversely, the bottomhole of HP gas wells above 450 bars with no active aquifer will sooner or later pass through a corrosive period, due to the presence of trapped water slugs, whereas the condensing zone at the top will never be corrosive.

\section{Prediction of Corrosion Rate and Material Selection}

An industry standard approach for predicting $\mathrm{CO}_{2}$ corrosion does not exist. There are no standards or guidelines like there are for $\mathrm{H}_{2} \mathrm{~S}$ cracking (e.g., ISO 15156).

Different relationships between environmental variables and tendency to sweet corrosion have been proposed. They range from the simplest "rules of thumb" based on $\mathrm{CO}_{2}$ partial pressure ${ }^{75}$ to complex predicting models.

Oil companies and research institutions have developed a large number of $\mathrm{CO}_{2}$ corrosion predicting models. ${ }^{6-85}$ Several models are mainly based on empirical correlations with laboratory data, while others are partly based on field data. In addition, some other models are based on mechanistic approaches of the different chemical and transport reactions. In 2010, an overview of different prediction models used in the oil and gas industry for evaluation of $\mathrm{CO}_{2}$ corrosion of carbon steel was presented. ${ }^{86}$ Models differ considerably in how they predict the effect of protective corrosion films and the effect of oil wetting on $\mathrm{CO}_{2}$ corrosion, and these two factors account for the most pronounced differences between models. ${ }^{86}$

Additionally, a set of the most used models were evaluated against field data. Depending on the field cases, different models were most successful in their prediction, and it was not possible to identify one or two models as better than others. ${ }^{87}$

Using the CORMED software for the quantitative assessment of the protectiveness leading parameters, Crolet et al. ${ }^{88}$ concluded that in any well producing reservoir water, only a sufficient presence of free HAc and the solubility of iron acetate can

\begin{tabular}{|c|c|c|c|}
\hline $\begin{array}{l}\text { Expected } \\
\text { corrosion }\end{array}$ & $\underset{\text { (bar) }}{\mathbf{P}_{\mathrm{CO}_{2}} \max }$ & & $\begin{array}{c}\text { in situ } \\
\text { HAc (mM) }\end{array}$ \\
\hline \multicolumn{4}{|l|}{ Condensed water } \\
\hline Low/acceptable & $<5$ & and & $<1$ \\
\hline High/unacceptable & $>5$ & or & $>1$ \\
\hline \multicolumn{4}{|l|}{ Reservoir water } \\
\hline Low/acceptable & - & & $<0.1$ \\
\hline High/unacceptable & - & & $>0.1$ \\
\hline
\end{tabular}

jeopardize the protectiveness of $\mathrm{FeCO}_{3}$ layers. In wells producing condensed water, only the very low $\mathrm{pH}$ values associated with high $\mathrm{P}_{\mathrm{CO}_{2}}$ figures can also jeopardize this protectiveness. Based on their algorithms, new prediction rules for downhole $\mathrm{CO}_{2}$ corrosion were proposed (Table II).

When selecting CRAs, environmental conditions that can affect its passive layer and cause localized corrosion have to be considered (i.e., chlorides, temperature, disrupted flow, and presence of sand). Additionally, process factors (i.e., mechanical damage by wire line operations and acidification) can also damage the passive layer and promote localized corrosion. For CRAs, the worst conditions for general and localized corrosion are normally associated with the maximum service temperature. Prediction models are not common for CRAs, and typically, application domains ${ }^{89}$ and even rules of thumb are used during their selection.

\section{SUMMARY: WHAT ARE THE CHALLENGES FOR THE FUTURE?}

High-pressure/high-temperature applications are pushing the limits of materials for oil and gas exploration and production technology. HP/HT plus the presence of aggressive environments mean a highly challenging scenario for OCTG. Under these conditions, requirements for pipes will include not only characteristics related to material properties but also connection properties and geometry tolerances to fulfill the well design requisites.

Material property requirements include high mechanical properties at ambient and at high temperatures (e.g., as high as $200-250^{\circ} \mathrm{C}$ ). Additionally, if $\mathrm{H}_{2} \mathrm{~S}$ is present in the environment, resistance to SSC may be required, depending also on the other environmental conditions. Even without $\mathrm{H}_{2} \mathrm{~S}$, contents of $\mathrm{CO}_{2}$, chlorides, and high temperatures and pressures can represent a risk of a high corrosion rate.

As discussed, the improvement of some of the required properties of steels can mean the impairment of others. Consequently, a careful balance is required and limits exist for the individual modification of the properties.

In light of this scenario, the following questions appear on our horizon:

1. What is the improvement level that can be achieved for properties of the currently used materials through the enhancement of material design and process conditions? In other words, how far from their limits regarding key properties are the currently used materials?

2. Which are the alternative new materials (e.g., nanomaterials) for the industry? Are there new options of bulk materials and/or surface treatments on more conventional materials?

3. Are new material technologies able to generate materials that represent a breakthrough with a quantitate jump in properties? 
Even after getting positive answers for our last questions at a laboratory scale, important challenges remain. After achieving promising results with new technology materials in laboratory conditions, industrial scale implementation is still a challenge. Aspects such as the production of lowcost and easily industrialized materials need to be managed.

The joint effort of the R\&D community together with pipe producers and the oil and gas exploration and production industry will be necessary to face these challenges.

\section{REFERENCES}

1. M.R. Simmons, Report of Offshore Technology Conference (OTC) presentation (Houston, TX: NACE International Oil and Gas Production, 2008).

2. A. Shadravan and M. Amani, Energy Sci. Technol. 4, 36 (2012).

3. NACE MR0175/ISO 15156 (2009) Petroleum and Natural Gas Industries-Materials for Use in $\mathrm{H}_{2} \mathrm{~S}$-Containing Environments in Oil and Gas Production (Houston, TX: NACE, 2003).

4. S. Papavinasam, J. Li, D. Emadi, A. Doiron, S. Salvador, J. Krausher, A. Shafeen, A. Pratt, and J.-P. Gravel (Paper C2012-0001259 Presentation at Corrosion 2012, Salt Lake City, UT, 11-15 March 2012).

5. Y-S. Choi and S. Nesic (Paper 11377 Presentation at Corrosion 2011, NACE International, Houston, TX, 13-17 March 2011).

6. A. Dugstad, B. Morland, and S. Clausen (Paper 11070 Presentation at Corrosion 2011, NACE International, Houston, TX, 13-17 March 2011).

7. L. Smith, C.H. Lee, D. Milanovic, and M. Billingham (Paper 2012-0001376 Presentation at Corrosion 2012, Salt Lake City, UT, 11-15 March 2012).

8. R.P. Gangloff, Comprehensive Structural Integrity, eds. I. Milne, R.O. Ritchie, B. Karihaloo, J. Petit, and P. Scott, vol 6. (New York: Elsevier Science, 2003), pp. 31-101.

9. R.P. Gangloff, Environment Induced Cracking of Materials (EICM-2), ed. S. Shipilov, R.H. Jones, J.-M Olive, and R.B. Rebak (Oxford, U.K.: Elsevier Science, 2007), pp. 141-166.

10. R.A. Oriani, Annu. Rev. Mater. Sci. 8, 327 (1978).

11. G.M. Pressouyre and I.M. Bernstein, Metall. Trans. A 9, 1571 (1978).

12. A.W. Thompson and I.M. Bernstein, eds., Effect of Hydrogen on Behavior of Materials (New York: The Metallurgical Society of AIME, 1976).

13. A.W. Thompson and N.R. Moody, eds., Hydrogen Effects in Materials (Warrendale, PA: TMS, 1996).

14. N.R. Moody and A.W. Thompson, eds., Hydrogen Effects on Material Behavior (Warrendale, PA: TMS, 1990)

15. M.J. Cancio, P. Bruzzoni, T. Perez, and J. Collet-Lacoste (Paper Proceedings Eurocorr 2009).

16. M.J. Cancio, T. Perez, J.R. Collet-Lacoste (Paper 09098 Presentation at Corrosion 2009, Atlanta, GA, 22-26 March 2009).

17. H.J. Grabke and E. Riecke, Mater. Technol. 34, 331 (2000).

18. K. Takai, Environmental Induced Cracking of Materials, ed. S. Shipilov, R.H. Jones, J.M. Olive, and R.B. Rebak (New York: Elsevier, 2008), p. 273.

19. G.M. Pressouyre, Acta Metall. 28, 895 (1980).

20. G.M. Pressouyre and I.M. Bernstein, Met. Trans. A 12, 835 (1981).

21. G.M. Pressouyre and I.M. Bernstein Report Number 036099-7 (Pittsburgh, Carnegie-Mellon University, 1977).

22. P. Marcus, eds., Corrosion Mechanisms in Theory and Practice (New York: Marcel Dekker, 2002).
23. M.J. Cancio, T.E. Perez, and J.R. Collet-Lacoste (Presentation at Eurocor 2007, Freiburg im Breisgau, Germany, 9-13 September 2007).

24. W. Beck, J.O.M. Bockris, J. McBreen, and L. Nanis, Proc. Roy. Soc. Lond. A 290 (1421), 220 (1966).

25. R.P. Gangloff, Environmental Induced Cracking of Materials, ed. S. Shipilov, R.H. Jones, J.M. Olive, and R.B. Rebak (Elsevier, New York, 2008), p. 141.

26. D.C. Ahn, P. Sofronis, and R.H. Dodds Jr, Int. J. Hydrogen Energy 32, 3734 (2007).

27. Y. Liang, P. Sofronis, and R.H. Dodds Jr, Mater. Sci. Eng. A 366, 397 (2004).

28. S. Cravero, R. Bravo, H. Ernst, M.J. Cancio, and T. Perez (Paper 09309 presented at Corrosion NACE 2009, Atlanta, GA, March 2009).

29. B.J. Berkowitz, J.J. Burton, C.R. Helms, and R.S. Polizzotti, Scr. Metall. 10, 871 (1976).

30. D.R. Baer, M.T. Thomas, and R.H. Jones, Metall. Trans. A 15A, 853 (1984).

31. M. Lu, P.S. Pao, T.W. Weir, G.W. Simmons, and R.P. Wei, Metall. Trans. A 12A, 805 (1981).

32. T. Zakroczymski 5th International Congress on Metallic Corrosion, vol 2 (Houston, TX: NACE, 1972), pp. 15-250.

33. B.J. Berkowitz and H.H. Horowitz, J. Electrochem. Soc. 129, 468 (1982).

34. R.N. Iyer, I. Takeuchi, M. Zamanzadeh, and H.W. Pickering, Corrosion 46, 460 (1990).

35. A. Kawashima, K. Hashimoto, and S. Shimodaira, Corrosion 32, 321 (1976).

36. G. Echaniz, C. Morales, and T. Pérez (Papers from EUROCORR '97 and EUROCORR '98), ed. P.S. Jackman and L.M. Smith (IOM Communications, 1999), p. 135.

37. NACE Standard TM0177-2005, Laboratory Testing of Metals for Resistance to Sulfide Stress Cracking and Stress Corrosion Cracking in $\mathrm{H}_{2} \mathrm{~S}$ Environments (Houston, TX: NACE, 2005).

38. G. Echaniz, T. Pérez, C. Pampillo, R.C. Newman, R.P.M Procter, and G.W. Lorimer (Paper 50 presented at Corrosion 97, NACE International, Houston, TX, 1997).

39. API Specification 5CT, Specification for Casing and Tubing, 9th ed. (Washington, D.C.: American Petroleum Institute, 2011).

40. M. Bonis and P. Thiam, Measurements of Corrosion Costs within Elfs Explorations and Production (Eurocorr 2000).

41. P. McIntyre, Corr. Manage. 46, 19 (2002).

42. M.B. Kermani and A. Morshed, Corrosion 59, 659 (2003).

43. S. Nesic, M. Nordsveen, R. Nyborg, and A. Stangeland (Paper 01040 presented at Corrosion 2001, NACE International, Houston, TX, 11-16 March 2001).

44. J.L. Crolet, N. Thevenot, and S. Nesic, Corrosion 54, 194 (1998).

45. A. Dugstad, H. Hemmer, and M. Seiersten (Paper 24 presented at Corrosion 2000, Paper 24, NACE International, Houston, TX, 2000).

46. A. Dugstad (Paper 24 presented at Corrosion 1998, NACE International, Houston, TX, 1998).

47. J. Amri, E. Gulbrandsen, and R.P. Nogueira, Electrochem. Commun. 10, 200 (2008).

48. J. L. Crolet and M. Bonis (Paper 160 presented at Corrosion 1983, NACE International, Houston, TX, 1983).

49. Y. Sun, K. George, and S. Nesic (Paper 03327 presented at Corrosion 2003, NACE International, Houston, TX, 2003).

50. J. Dougherty (Paper 04376 presented at Corrosion 2004, NACE International, Houston, TX, 2004).

51. J.L. Crolet, N. Thevenot, and A. Dugstad (Paper 99024 presented at Corrosion, NACE International, Houston, TX, 1999).

52. Y. Garsany (Paper 02273 at Corrosion 2002, NACE International, Houston, TX, 2002).

53. J.L. Crolet and M. Bonis (Paper 05272 presented at Corrosion 2005, NACE International, Houston, TX, 2005).

54. D.A. Lopez, T. Perez, and S. Simison, Mater. Des. 24, 561 (2003). 
55. D. López, W. Schreiner, S. de Sánchez, and S. Simison, Appl. Surf. Sci. 207, 69 (2003).

56. C. Palacios and J. Shadley, Corrosion 47, 122 (1991).

57. S. Al-Hassan, B. Mishra, D.L. Olson, and M.M. Salama, Corrosion 54, 480 (1998).

58. S.D. Kapusta and S.C. Canter (Paper 10 presented at Corrosion 1994, NACE International, Houston, TX, 1994).

59. S. Nesic, J. Postlethwaite, and S. Olsen, Corrosion 52, 280 (1996).

60. P.I. Nice and M. Ueda (Paper 98003 presented at Corrosion 1998, NACE International, Houston, TX, 1998).

61. M.B. Kermani, J.C. Gonzalez, C. Linne, M. Dougan, and R. Cochrane (Paper 01065 presented at NACE Annual Corrosion Conference, 2001).

62. B. Kermani, J.C. Gonzalez, G. López Turconi, D. Edmonds, G. Dicken, and L. Scoppio (Paper 03116 presented at NACE Annual Corrosion Conference, 2003).

63. B. Kermani, J.C. Gonzalez, G. López Turconi, T. Perez, and C. Morales (Paper 04111 presented at NACE Annual Corrosion Conference, 2004).

64. L. Pigliacampo, J.C. Gonzales, G López Turconi, T. Perez, C. Morales, and M.B. Kermani (Paper 06133 presented at NACE Annual Corrosion Conference, 2006).

65. Tenaris Internal Report.

66. S.N. Smith and J.L. Pacheco (Paper 02241 presented at Corrosion 2002, NACE International, Houston, TX, 2002).

67. S.N. Smith and M. Joosten (Paper 06115 presented at Corrosion 2006, NACE International, Houston, TX, 2006).

68. A.K. Dunlop, H.L. Hassell, and P.R. Rhodes (Paper 46 presented at Corrosion/83, NACE International, Houston, TX, 1983).

69. R. Nyborg, Guidelines for Prediction of $\mathrm{CO}_{2}$ Corrosion in Oil and Gas Production Systems, IFE/KR/E-2009/003 (Kjeller, Norway: Institute for Energy Technology, 1 September 2009).

70. NACE TG 305 Proposed Standard Practice, "Wet Gas Internal Corrosion Direct Assessment Methodology for Pipelines," Draft 5 (27 August 2010).

71. S.N. Smith (Paper 11065 presented at Corrosion/2011, NACE International, Houston, TX, 2011).

72. M.R. Bonis, M. Girgis, K. Goerz, and R. MacDonald (Paper 06122 presented at Corrosion/2006, NACE International, Houston, TX, 2006).

73. M. Bonis (Paper 09564 presented at Corrosion 2009, NACE International, Houston, TX, 2009).
74. J.L. Crolet and M. Bonis (Paper 10365 presented at Corrosion 2010, NACE International, Houston, TX, 2010).

75. H.G. Byars, "Corrosion Control in Petroleum Production" TPC Publication 5, 2nd ed. (Houston, TX: NACE International, 1999).

76. A.M. Halvorsen and T. Søntvedt (Paper 42 presented at CORROSION/99, NACE International, Houston, TX, 1999).

77. S. Olsen, A.M. Halvorsen, P.G. Lunde, and R. Nyborg (Paper 05551 presented at CORROSION/2005, NACE International, Houston, TX, 2005).

78. B.F.M. Pots, R.C. John, I.J. Rippon, M.J.J. Simon Thomas, S.D. Kapusta, M.M. Girgis, and T. Whitham (Paper 02235 presented at CORROSION/2002, NACE International, Houston, TX, 2002).

79. B.F.M. Pots and S.D. Kapusta (Paper 05550 presented at CORROSION/2005, NACE International, Houston, TX, 2005).

80. B. Hedges, R. Chapman, D. Harrop, I. Mohammed, and Y. Sun (Paper 0555 presented at CORROSION/2005, NACE International, Houston, TX, 2005).

81. C. de Waard, U. Lotz, and D.E. Milliams, Corrosion 47, 976 (1991).

82. C. de Waard, U. Lotz, and A. Dugstad (Paper 128 presented at CORROSION/95, NACE International, Houston, TX, 1995).

83. Y.M. Gunaltun (Paper 27 presented at CORROSION/96, NACE International, Houston, TX, 1996).

84. C. de Waard, L. Smith, and B.D. Craig (Paper 03629 presented at CORROSION/2003, NACE International, Houston, TX, 2003).

85. L. Smith and C. de Waard (Paper no. 05648 presented at CORROSION/2005, NACE International, Houston, TX, 2005).

86. R. Nyborg (Paper 10371 presented at Corrosion 2010, NACE International, Houston, TX, 2010).

87. R. Nyborg (Paper 06118 presented at Corrosion 2006, NACE International, Houston, TX, 2006).

88. J.L. Crolet and M. Bonis (Paper 10363 presented at Corrosion 2010, NACE International, Houston, TX, 2010).

89. B.D. Craig and L. Smith, Corrosion Resistant Alloys (CRAs) in the Oil and Gas Industry-Selection Guidelines Update," Nickel Institute Technical Series No 10 073, 3rd ed. (September 2011). 